\title{
Reservoir Characterization of the Early Cretaceous Sarmord and Garagu Formations from Atrush-1 and Mangesh-1 Wells, Kurdistan Region, Iraq
}

\author{
Ayad N. F. Edilbi', Wrya J. Mamaseni2, Mahdi Kh. Aswad², Bahroz Gh. Abdullah ${ }^{3,4}$, \\ Falah Kh. Al-Jaboury5, Govand H. Sherwani6, Nadhir Al-Ansari ${ }^{*}$ \\ ${ }^{1}$ Department of Petroleum Geosciences, Faculty of Science, Soran University, Soran, Kurdistan Region, Iraq \\ ${ }^{2}$ Geology Department, College of Science, Salahaddin University, Erbil, Kurdistan Region, Iraq \\ ${ }^{3}$ Geology Department, College of Science, University of Duhok, Duhok, Kurdistan Region, Iraq \\ ${ }^{4}$ Department of Petroleum Engineering, College of Engineering, American University of Kurdistan, Sulaimaniya, \\ Kurdistan Region, Iraq \\ ${ }^{5}$ Petroleum Engineering Department, Knowledge University, Erbil, Kurdistan Region, Iraq \\ ${ }^{6}$ Department of Civil Engineering, Cihan University-Erbil, Erbil, Kurdistan Region, Iraq \\ ${ }^{7}$ Lulea University of Technology, Lulea, Sweden \\ Email: *nadhir.alansari@ltu.se
}

How to cite this paper: Edilbi, A.N.F., Mamaseni, W.J., Aswad, M.Kh., Abdullah, B.Gh., Al-Jaboury, F.Kh., Sherwani, G.H. and Al-Ansari, N. (2021) Reservoir Characterization of the Early Cretaceous Sarmord and Garagu Formations from Atrush-1 and Mangesh-1 Wells, Kurdistan Region, Iraq. Open Journal of Geology, 11, 509-524.

https://doi.org/10.4236/ojg.2021.1110027

Received: August 20, 2021

Accepted: October 23, 2021

Published: October 26, 2021

Copyright $\odot 2021$ by author(s) and Scientific Research Publishing Inc. This work is licensed under the Creative Commons Attribution International License (CC BY 4.0).

http://creativecommons.org/licenses/by/4.0/ (c) (i) Open Access

\begin{abstract}
Petrophysical properties of the Early Cretaceous Sarmord and Garagu formations from the Atrush and Sarsang Blocks in the Kurdistan Region are studied. These formations are generally composed of limestones and dolomitic limestones interbedded with thin to medium layers of yellowish-gray marl (calcareous mudstone). The current study shows that the average shale volume in the Sarmord and Garage formations is between $16 \%$ and $20 \%$. In Atrush-1 Well, the average porosity ratio of the Sarmord and Garagu formations is fair to good (15\% and $11 \%$, respectively). However, in Mangesh-1 Well, the porosity value is poor; it is around $4 \%$ on average. Generally, most of the hydrocarbons that have been observed within the pore spaces are residual oil type in Atrush-1 Well and movable hydrocarbon type in Mangesh-1 Well. In Atrush-1 Well, out of $362 \mathrm{~m}$ thickness of both formations, only 180 $\mathrm{m}$ is considered to be a pay zone; whereas, the pay zone is just around $8.0 \mathrm{~m}$ thick out of $347 \mathrm{~m}$ of the total thickness. According to the calculated porosity values, the Garagu and Sarmord formations are not considered as good reservoirs in the studied wells, with the exception of Atrush-1 Well where the Sarmord Formation has fair potential reservoir characteristics.
\end{abstract}




\section{Keywords}

Sarmord Formation, Garagu Formation, Reservoir Characterization, Hydrocarbons Saturation, Net Pay

\section{Introduction}

Wireline logs represent one of the most common techniques used mainly by petrophysics and petroleum geologists in order to interpret data and information retrieved from wells, including physical properties of the rock formations; for example, lithology, porosity value, depth and thickness. Moreover, wireline logs are very useful tools to distinguish between water, oil and gas contacts, and the estimation of hydrocarbons within the reservoir units [1]. In the current study, the corrected well log data were used to determine the lithology, porosity, hydrocarbon saturation, and water saturation from the Sarmord and Garagu formations from Mangesh-1 and Atrush-1 Wells in the Sarsang and Atrush Blocks, respectively.

Mangesh-1 Well is situated within the Sapna valley in the Sarsang Block. This block is located in the northern limb of Gara Anticline, about $50 \mathrm{~km}$ northeast of Duhok City. It is structurally very complex and contains several folds with horst and graben structures [2]. Atrush-1 Well, on the other hand, is located within the Atrush Block, which is located about $25 \mathrm{~km}$ northeast of Duhok City [3] (Figure 1). The structure of the Atrush block is an anticline and fault structure developed along a shallow thrust zone that oriented east-west in the Zagros Basin.

In the study area, the Sarmord Formation is underlain by the Garagu Formation and overlain by the Qamchuqa Formation. The formation has a thickness of $187 \mathrm{~m}$ and $180 \mathrm{~m}$ in Mangesh-1 and Atrush-1 Wells, respectively. Garagu Formation, on the other side, is underlain by Chia Gara Formation, and its thickness varies from $182 \mathrm{~m}$ in Atrush-1 Well to $160 \mathrm{~m}$ in Mangesh-1 Well.

Until now, little attention has been paid to reservoir characteristics of the Lower Cretaceous successions in the Kurdistan Region. The role of the Sarmord and Garagu formations within the petroleum systems context in the area is still debatable. However, Mamaseni et al. [4] in a study on Lower Cretaceous formations from Shaikhan oilfield, found that the lower part of Sarmord Formation had a poor porosity (5\%); though, the upper part of the formation has a fair porosity (up to 13\%). Edilbi et al. [5] also concluded that the Sarmord Formation has very low porosity and is not considered a significant reservoir in the Kirkuk area. This study aims to evaluate the reservoir quality of the Sarmord and Garagu formations in two blocks in the High Folded Zone from Kurdistan Region.

\section{Geological Background}

Late Tithonian-Early Turonian Megasequence (AP8) was deposited within a 


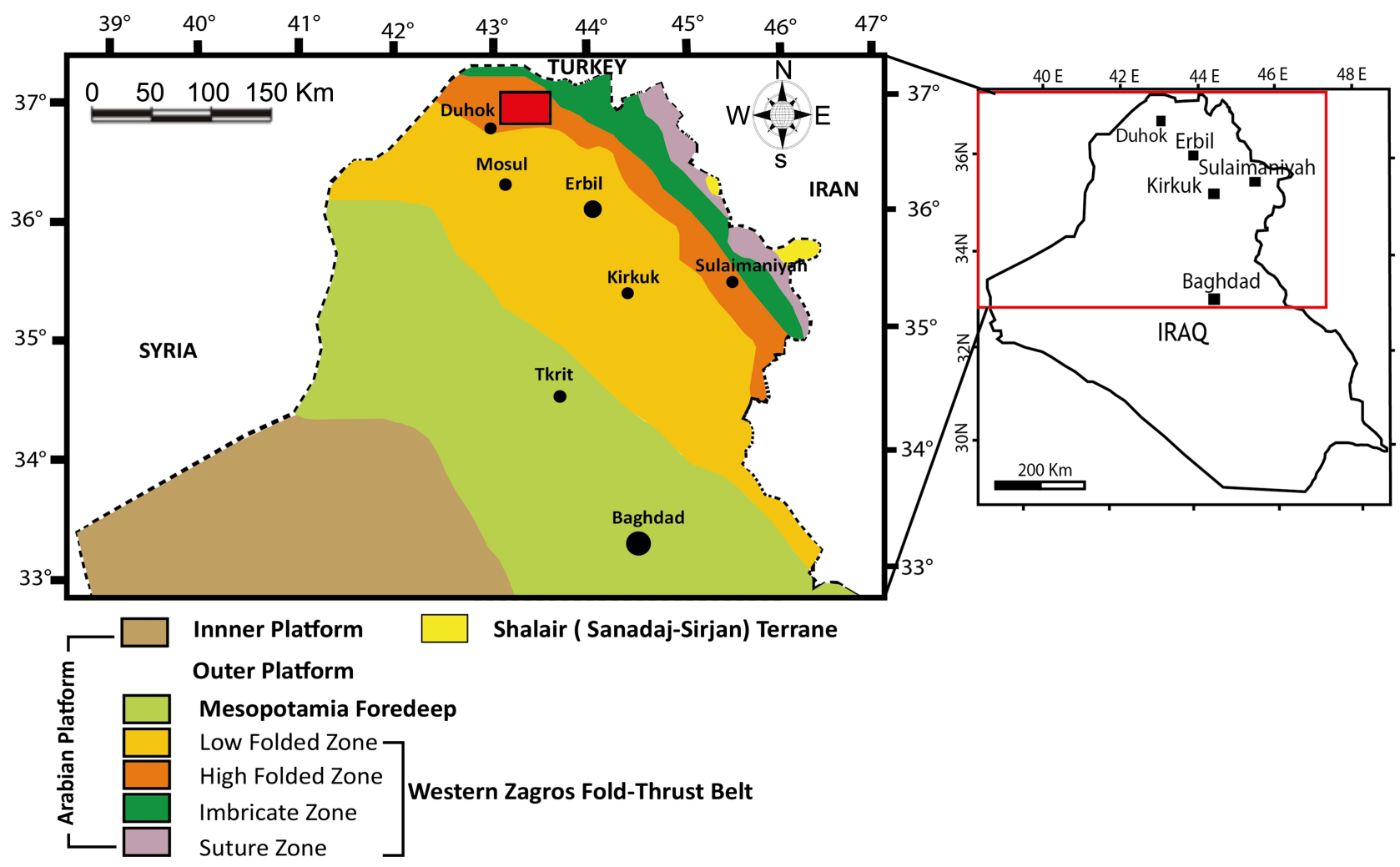

(a)

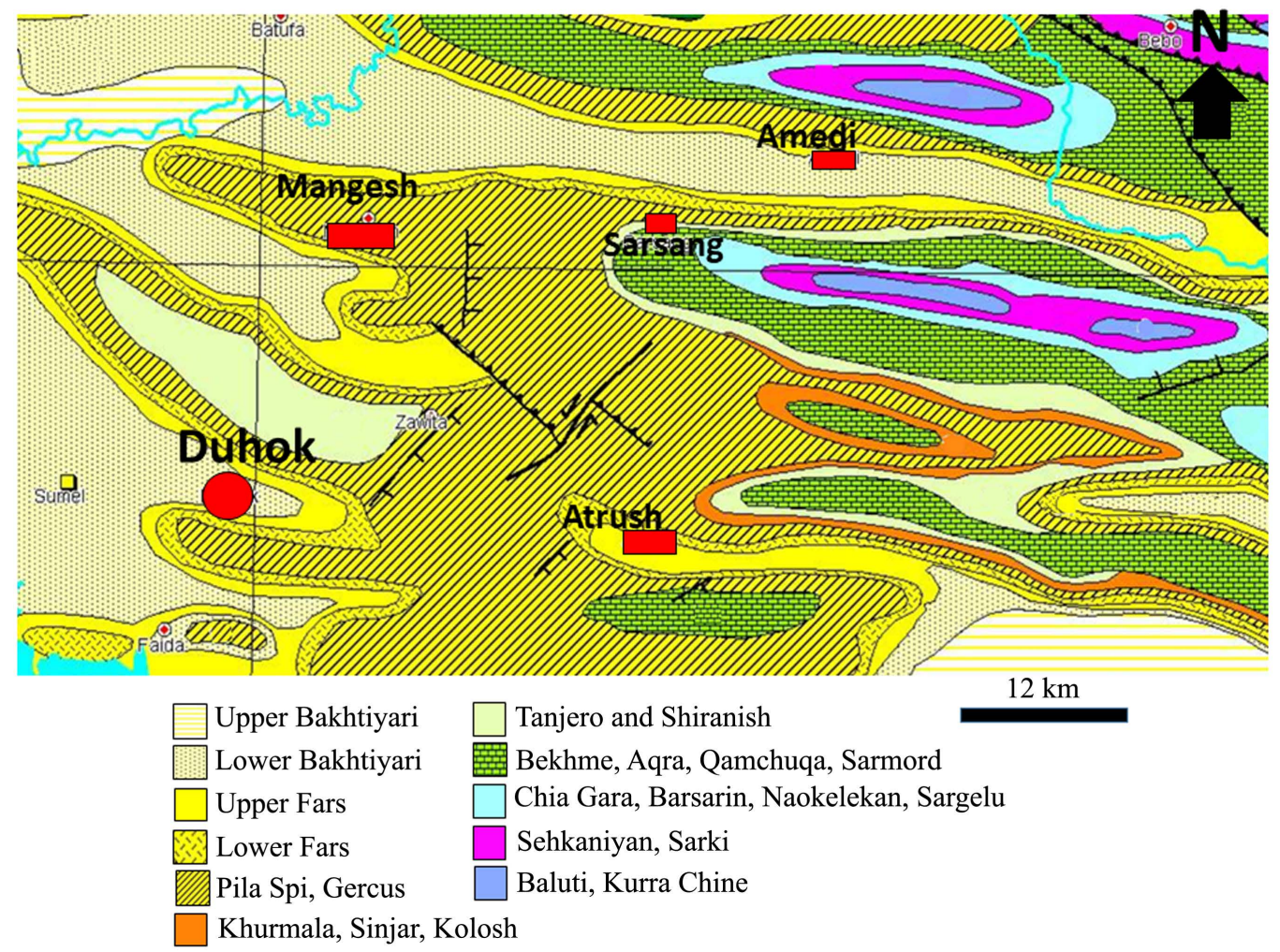

(b)

Figure 1. (a) Location of the studied area (red rectangular) on tectonic zones of Iraq [6]; (b) Geological Map of the study area (Modified from Stevanovic et al. [7]). 
large intra-shelf basin contemporaneous with a new phase of ocean floor spreading in the Southern Neo-Tethys [8]. Because of the opening of the Southern Neo-Tethys which caused drifting away of a narrow microcontinent, a new passive margin of carbonate ridge was formed along the northeast margin of the Arabian Plate. In the western margin of the Mesopotamian Basin, the Rutba Uplift was developed. The Late Tithonian-Hauterivian Sequence in Iraq comprises several formations; namely, are Sulaiy, Makhul, Chia Gara (Karimia), Yamama (Garagu and Zangura), Ratawi and Lower Sarmord formations.

The Garagu Formation was first introduced by Wetzel in [9] in the Gali Garagu from the Chia Gara anticline in the High folded Zone of Northern Iraq (Kurdistan Region) (Figure 2). The Lower Cretaceous Garagu Formation has been observed in many drilled wells and outcrops in the northwest of Iraq [10]. This formation could be defined as a mixed carbonate-siliciclastic succession. Lithologically, the Garagu Formation is divided into three distinct units. The lower and upper parts are comprised of limestones, oolitic limestones and sandstones, whereas the middle part is made of marls, marly limestone and limestone beds. The formation is believed to be a good hydrocarbon reservoir in some subsurface sections [11]. The Garagu Formation was deposited in a shallow water environment with two high-energy belts in the lower and upper parts [9] [12].

Concerning the Sarmord Formation, it was defined by Wetzel in [9] in the Surdash Anticline from the High Folded Zone in the Sulaimaniya area of NE Iraq. In its type section, the formation comprises $455 \mathrm{~m}$ thickness of homogeneous, brownish, and bluish-gray marls, with units of the argillaceous limestones. The age of the formation was suggested as Valanginian-Aptian by [9]. Aqrawi et al. [11] divided the Sarmord Formation into two parts, namely Lower and Upper Sarmord. The Upper Sarmord is absent in the High Folded Zone of the northeastern part of Iraq, similarly, the type section of Sarmord Formation includes only the Lower Sarmord part. It is suggested that the depositional environment of the formation is a deep inner shelf to outer shelf environments [9] [11].

\section{Materials and Methods}

In this research, the well log data were used to investigate the reservoir quality of both Sarmord and Garagu formations. For interpretation of these data, the Interactive Petrophysics software (IP V3.5, 2008) was run in order to estimate the reservoir characteristics of the studied formations. The LAS files are important for Interactive Petrophysics (IP) program to run, especially those which have suites of gamma ray, neutron, density, and resistivity logs. The reading measurements are set as one reading per 0.1524 meters. Gamma ray $\log (G R)$ is usually used to measure the natural radioactivity of the formation. Thus, it is used to determine the volume of shale. The resistivity of a formation for its matrix and fluid in the pores is considered as true resistivity $\left(R_{t}\right)$, which is obtained from deep resistivity log such as Deep Induction Log or Deep Lateral Log. On 


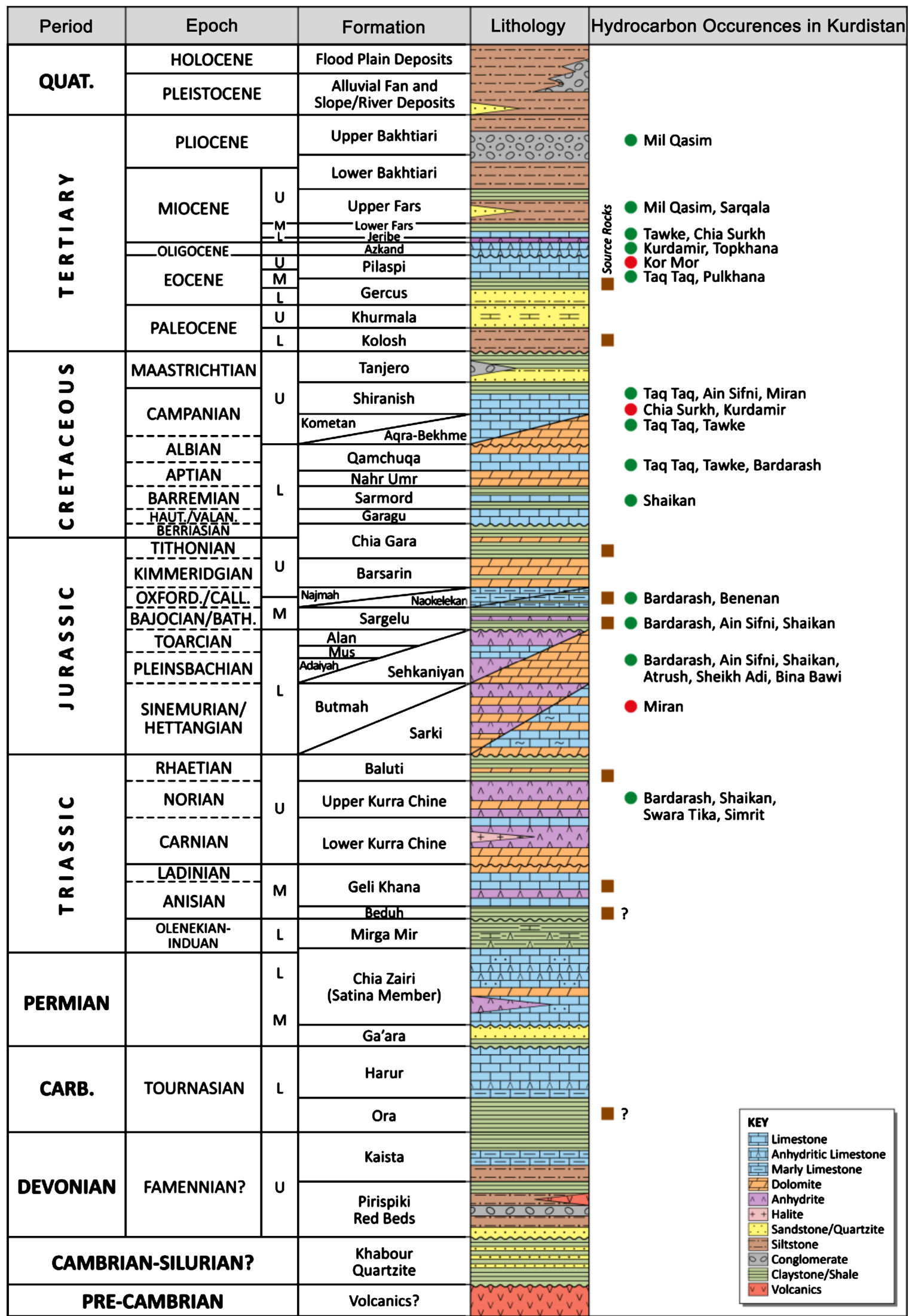

Figure 2. General stratigraphy and hydrocarbons occurrences in Kurdistan Region [13]. 
the other hand, the resistivity of the flushing zone can be measured by Microspherical Focused Logs. The IP V3.5 software was also used to determine the Temperature Gradient model to generate a continuous temperature curve for each well (Table 1). Practically, the formation water resistivity with Archie parameters such as saturation exponent $(n)$ and cementation exponent $(m)$ can be calculated from Pickett plot method, which is the relationship between true resistivity and effective porosity. The porosity $(\Phi)$ can be determined from several types of porosity logs, for example, sonic, density and neutron logs. The water saturation and permeability were calculated by Archie [14] and Timur [15] equations, respectively. The following equations were used to evaluate reservoir quality in this research.

\subsection{Shale Volume Estimation}

Shale volume can be measured from the gamma ray through the following steps:

Calculating the Gamma Ray Index $\left(I_{G R}\right)$ :

$$
I_{G R}=\left(G R_{\log }-G R_{\min }\right) /\left(G R_{\max }-G R_{\min }\right)
$$

Transforming the Gamma Ray Index into shale content using the empirical equation for old rocks:

$$
V_{s h}=0.33\left(2^{2 * I_{G R}}-1\right)
$$

where:

$I_{G R}$ : Gamma Ray Index;

$G R_{\mathrm{log}}$ : Gamma Ray log reading of formation;

$G R_{\min }$ : Minimum Gamma Ray reading in the clean zone, (clean sand or carbonate);

$G R_{\max }$ : Maximum Gamma Ray reading in shale zone;

$V_{\text {sh }}$ : Volume of shale.

\subsection{Porosity}

The following equation is used to find out the total porosity from density and neutron porosities.

$$
\Phi_{N D}=\frac{\Phi_{N}+\Phi_{D}}{2}
$$

where:

$$
\begin{aligned}
& \Phi_{N}: \text { Neutron Porosity; } \\
& \Phi_{D} \text { : Density Porosity. }
\end{aligned}
$$

Table 1. Temperature and total depth for the studied wells.

\begin{tabular}{cccc}
\hline Wells & BHT $\left({ }^{\circ} \mathrm{C}\right)$ & Surface Temp. $\left({ }^{\circ} \mathrm{C}\right)$ & Total Depth $(\mathrm{m})$ \\
\hline Atrush-1 & 54.00 & 25.70 & 3400 \\
Mangesh-1 & 60.38 & 26.00 & 4600
\end{tabular}


The relationship between total porosity $\left(\Phi_{t}\right)$ and effective porosity $\left(\Phi_{e}\right)$ can be calculated from the below equation:

$$
\Phi_{e}=\Phi_{t} *\left(1-V_{s h}\right)
$$

\subsection{Water Saturation $\left(S_{w}\right)$}

Water saturation of the uninvaded zone of a reservoir is estimated from the Archie's [14] formula:

$$
S_{w}=\left(\frac{a}{\Phi^{m}} * \frac{R_{w}}{R_{t}}\right)^{\frac{1}{n}}
$$

where:

$S_{w}:$ Water Saturation, fraction;

$R_{w}:$ Formation Water Resistivity, ohm-m;

$R_{i}$ True formation resistivity for the uninvaded zone, ohm-m;

$\Phi$ : Effective Porosity, and, $a, n$, and $m$ : Archie's parameters, dimensionless.

The water saturation of the formation's flushed zone $\left(S_{x o}\right)$ depends on Archie's equation as following:

$$
S_{x o}=\left(\frac{a}{\Phi^{m}} * \frac{R_{m f}}{R_{x o}}\right)^{\frac{1}{n}}
$$

\subsection{Hydrocarbon Saturation $\left(S_{h c}\right)$}

The hydrocarbon saturation can be derived from the water saturation via the following equation:

$$
S_{h c}=1-S_{w}
$$

Hydrocarbon saturation is normally discriminated into the residual hydrocarbon $\left(S_{h r}\right)$ or non-exploitable and the movable hydrocarbon $\left(S_{h m}\right)$ or exploitable as follow:

$$
S_{h c}=S_{h r}+S_{h m}
$$

\section{Results}

Shale volume from the rock formations can be measured by using gamma ray log. The more shale present, the more radioactive the formations are; hence, the more gamma ray counts. It is believed that low shale formations are usually considered to be a better reservoir; however, the increase in the volume of shale content reduces the effectiveness of reservoir capacity. As shown in Figure 3, the volume of shale in Sarmord Formation generally ranges from $13 \%$ to $19 \%$, whereas it increases in the Garagu Formation, ranging from $18 \%$ to $22 \%$. The sonic-neutron and neutron-density cross plots are used to determine the lithology of the formations. Both methods are widely used to make the separation between sandstone, limestone, and dolomite in a cross plot [16]. Each cross plot is a chart based on the slope and intersects with two porosity logs [17]. In this study, 


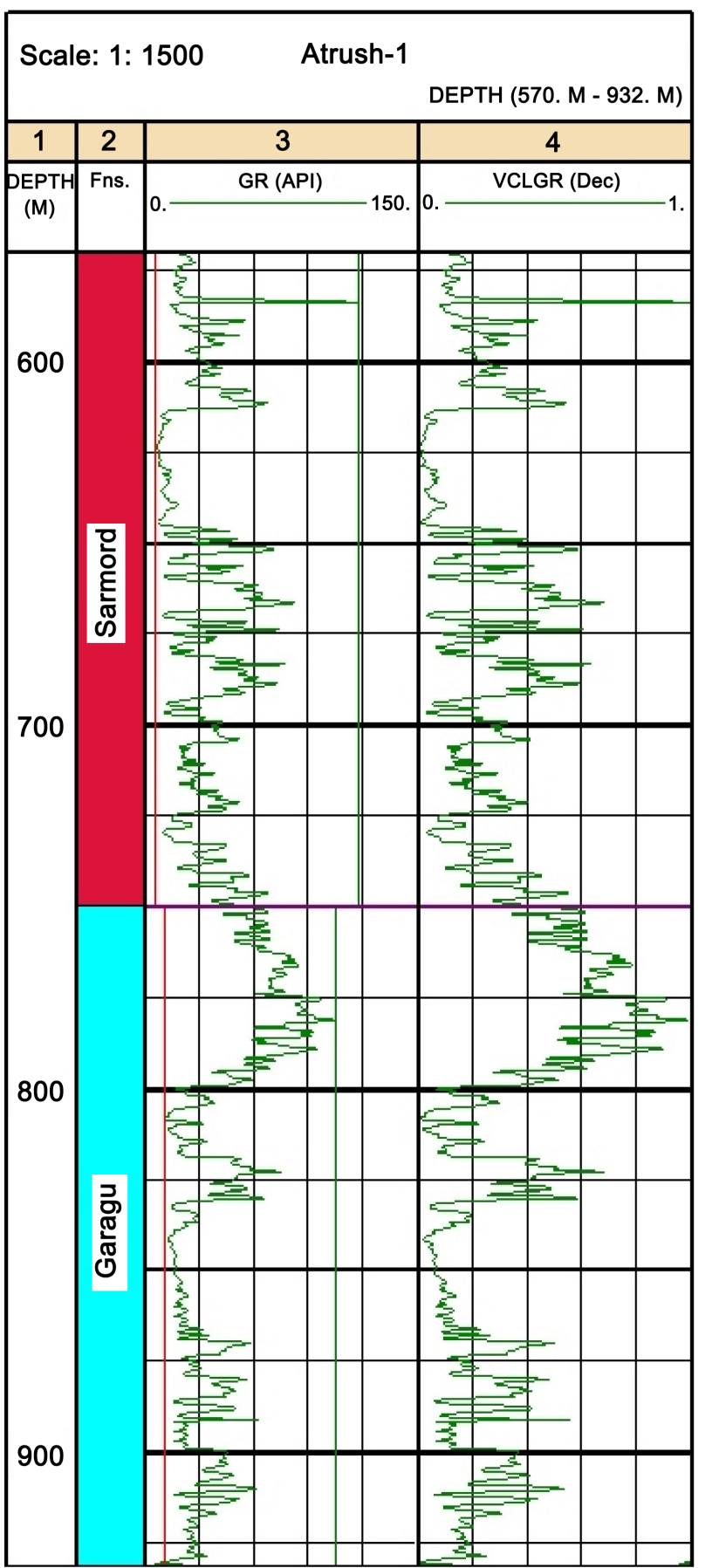

(a)



(b)

Figure 3. Volume of shale of the Sarmord and Garagu formations in Atrush-1 Well (a) and Mangesh-1 Well (b).

neutron-density, the cross plot was used to determine lithology for the studied formations, except Garagu Formation in Mangesh-1 Well in which its lithology was determined via sonic-neutron cross plot. The neutron porosity and bulk density data for the Sarmord Formation were plotted on the limestone line which reveals that the dominant lithology in the formation is limestone (Figure 4), whereas the Garagu Formation comprises limestone and dolomitic limestone. 


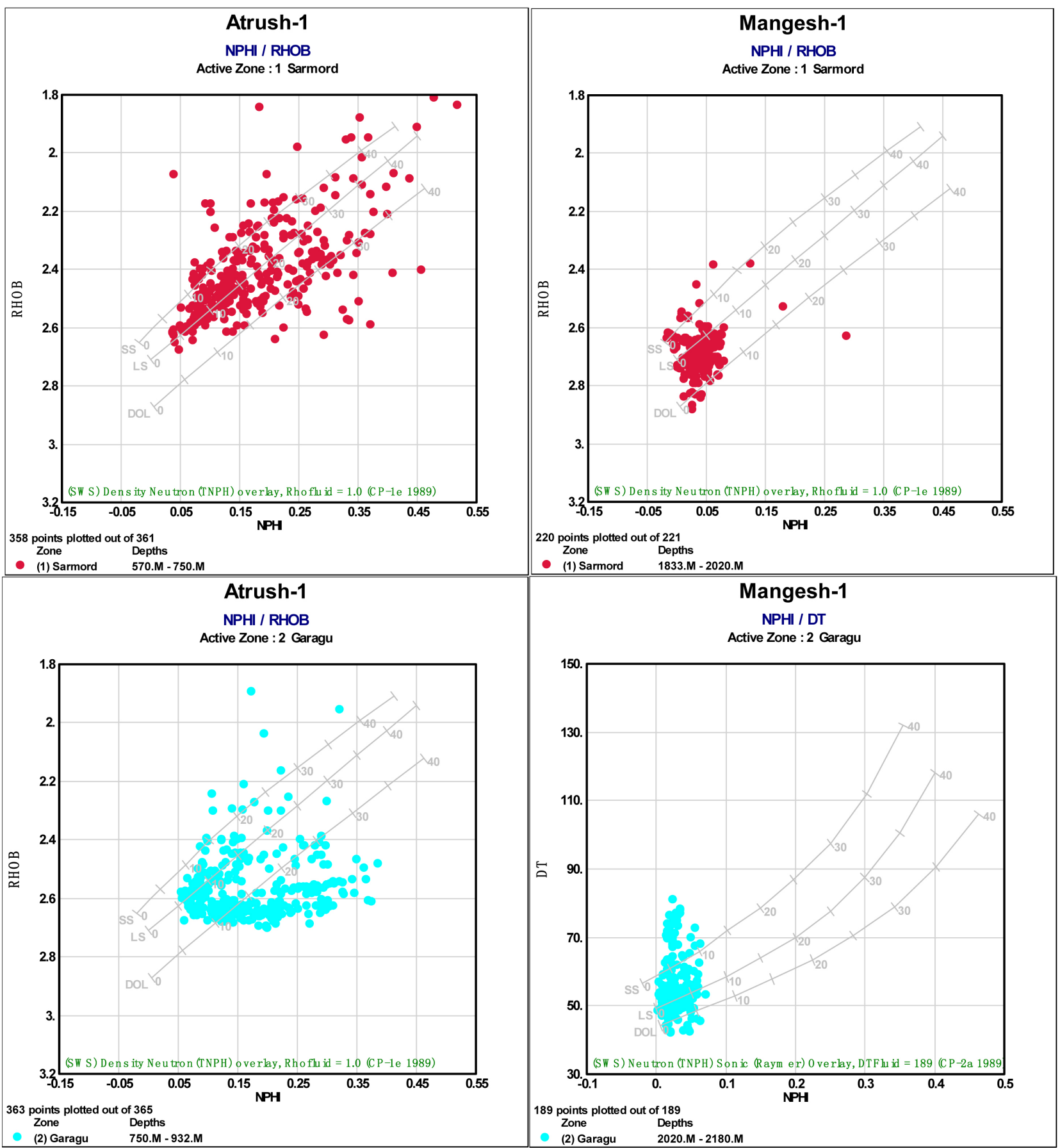

Figure 4. Neutron-density and neutron-sonic cross plot for the Sarmord and Garagu in Atrush-1 and Mangesh-1 Wells.

Moreover, due to the effect of borehole enlargement on bulk density logs, some points were scattered.

Porosity is one of the essential attributes of a reservoir, which is concerned to the ratio of the whole pore space in a rock sample to its bulk volume [18] [19]. A combination of the density and neutron logs can be used to estimate porosity from logs. The porosity that is obtained directly from logs without correction for clay content is regarded as total porosity, whereas effective porosity is the resul- 
tant porosity that is achieved after the removal of the effect of clay content. It is believed that in the no-shale intervals, the total porosity equals the effective porosity [20]. Generally, due to the impact of compaction and cementation on the reservoir rocks, the values of porosity are greatly reduced in the ancient and deeper reservoir rocks [21].

The high values of porosity have been recorded from the Sarmord Formation in Atrush-1 Well, reaching up to $15 \%$. On the other hand, the porosity values for the Sarmord and Garagu formations in Mangesh-1 are very low (Table 2).

The principle of the Pickett plots depends on the double logarithm plot of a resistivity measurement on the $\mathrm{x}$-axis versus porosity measurement on the $\mathrm{y}$-axis, and it is used to appraisal the formation water resistivity $\left(R_{w}\right)$. After plotting the points, the resulted straight line represents constant water saturations, and from it, the water resistivity can be determined. As shown in Table 3 and Figure 5, the formation water resistivity for studied zones show the water resistivity's

Table 2. Total and effective porosity ratios for the Sarmord and Garagu formations in the studied wells.

\begin{tabular}{cccc}
\hline Wells & Formations & Average PHIT & Average PHIE \\
\hline \multirow{2}{*}{ Atrush-1 } & Sarmord & 0.15 & 0.14 \\
& Garagu & 0.11 & 0.09 \\
\hline \multirow{2}{*}{ Mangesh-1 } & Sarmord & 0.04 & 0.03 \\
& Garagu & 0.04 & 0.03 \\
\hline
\end{tabular}

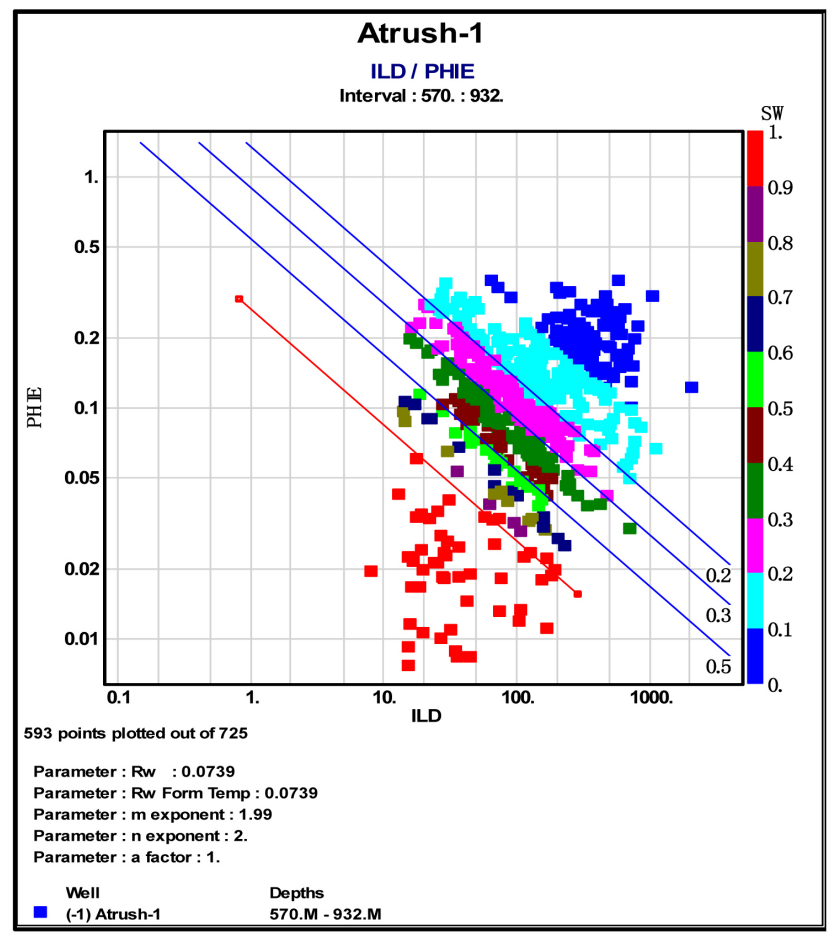

(a)

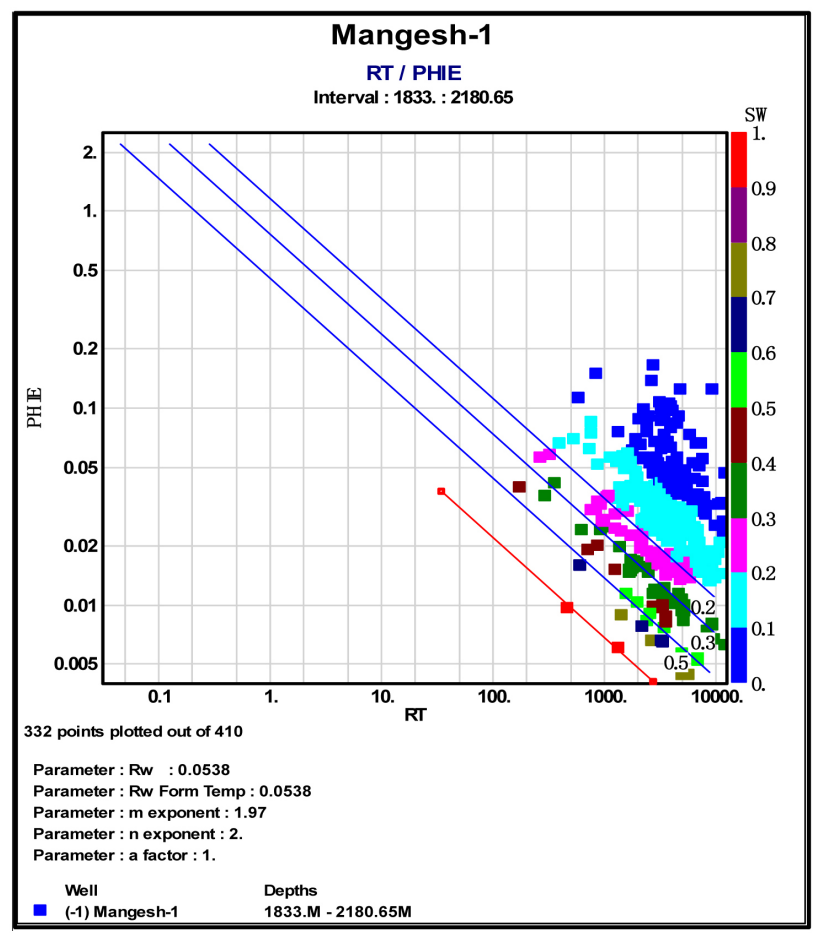

(b)

Figure 5. Formation water resistivity of the Sarmord and Garagu formations in Atrush-1 (a) and Mangesh-1 (b) Wells. 
Table 3. Water resistivity (Rw), Archie parameters, and Mud filtrate (Rmf) for the studied wells.

\begin{tabular}{ccccccc}
\hline Wells & Measured $\mathbf{R}_{\mathrm{mf}}$ & $\mathbf{R m f}$ at BHT & $\mathbf{m}$ & $\mathbf{n}$ & $\mathbf{a}$ & $\mathbf{R}_{\mathrm{w}}$ \\
\hline Atrush-1 & $0.09 @ 25.70$ & $0.06 @ 54.00$ & 1.99 & 2 & 1 & 0.074 \\
Mangesh-1 & $0.21 @ 26.00$ & $0.12 @ 60.38$ & 1.97 & 2 & 1 & 0.054 \\
\hline
\end{tabular}

value, which seems to be uncontaminated by drilling mud that saturates the porous formation.

Water saturation is defined as the amount of pore volume in a rock that is filled with formation water and is expressed as a decimal fraction or as a percentage [1]. Water saturation of the flushed zone is usually used to determine the movable hydrocarbon in the rocks. If the porosity value of the flushed zone is much higher than water saturation, then hydrocarbons in the flushed zone (Sxo) have probably been moved from the zone nearest the borehole by the invading drilling fluids [1]. In this research, the values of the flushed zone are greater than water saturation. This might indicate that the formations have good movable hydrocarbon content, especially in Mangesh-1. Movable hydrocarbon is represented by the yellow color on the computer processing interpretation (CPI) and the residual hydrocarbon is shown by the green color (Figure 6).

\section{Discussion}

The increase in the content of shale in a reservoir causes decreases in reservoir potentiality, which in turn is resulted from decreasing porosity and permeability [22]. The date of gamma ray log from Atrush-1 Well shows that the Sarmord Formation has around $13 \%$ shale content, while the shale volume increases in the Garagu Formation up to $18 \%$.

The Neutron-density cross plot shows that the Sarmord Formation consists of limestone and dolomitic limestone, whereas the Garagu Formation is composed of limestones, dolomites, and dolomitic limestones with subordinate units of shale. The average values of shale volume in the Garagu and Sarmord formations from Mangesh-1 Well are very close; it is $18 \%$ in the former and 19\% in the latter.

According to Levorsen [23] and Gluyas and Swarbrick [24] the porosity values of less than $5 \%$ can be neglected, the values between $5 \%-10 \%$ indicate poor quality, the values between $15 \%-20 \%$ show good quality, and the values greater than $20 \%$ are regarded as very good quality.

Although in some intervals the values of porosity may reach $35 \%$, the general values of porosity of the Sarmord Formation in Atrush-1 range from 5\% to 19\% ( $15 \%$ on average); it shows poor-fair porosity in the lower part of the formation, whereas good porosity is recorded in its upper part. Unlike the Sarmord Formation, the average values of porosity for the Garagu Formation range between 5\% and $16 \%$ ( $11 \%$ in total average), indicating good porosity in the lower part of the formation, and poor porosity in the upper part of the formation. 


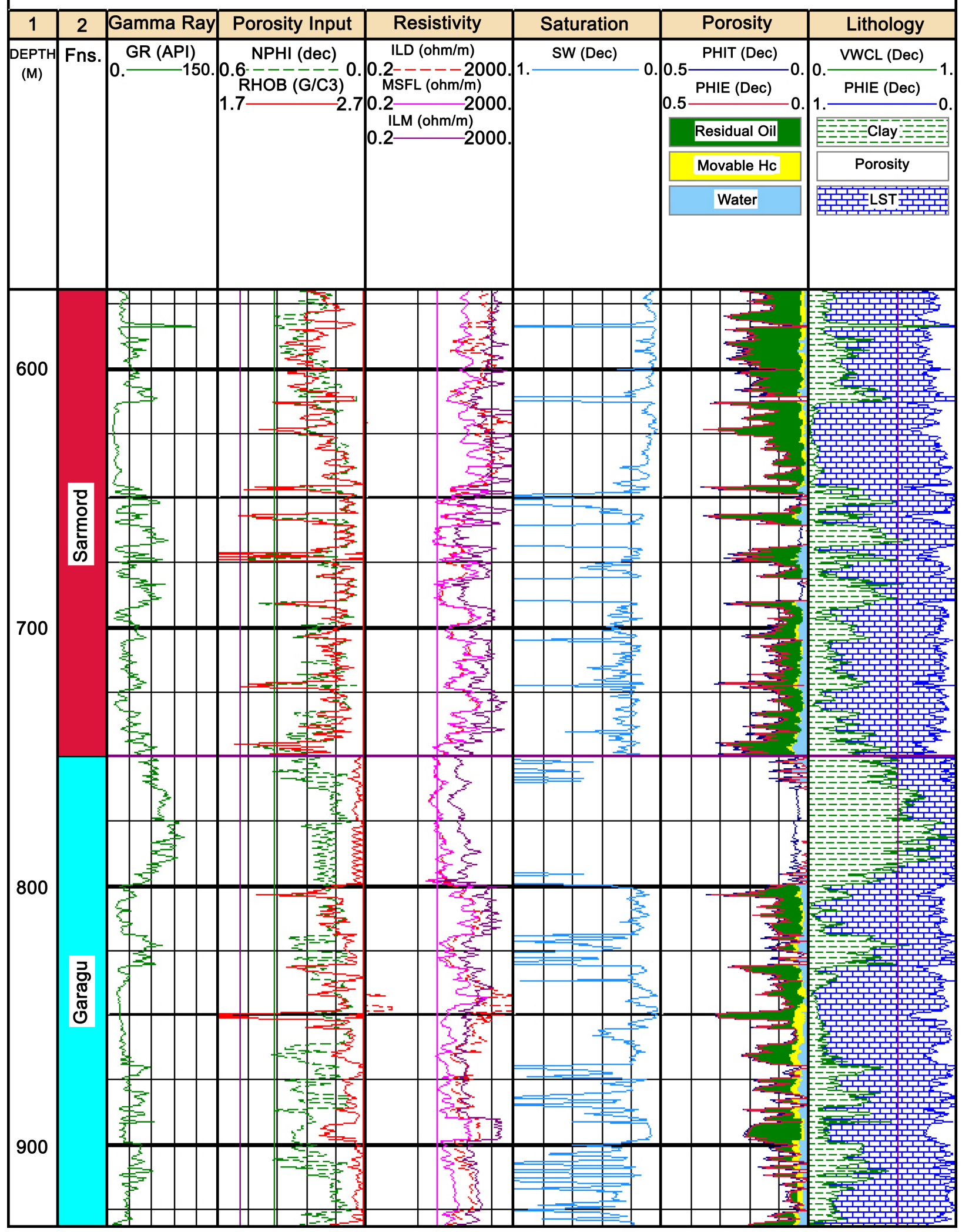

(a) 


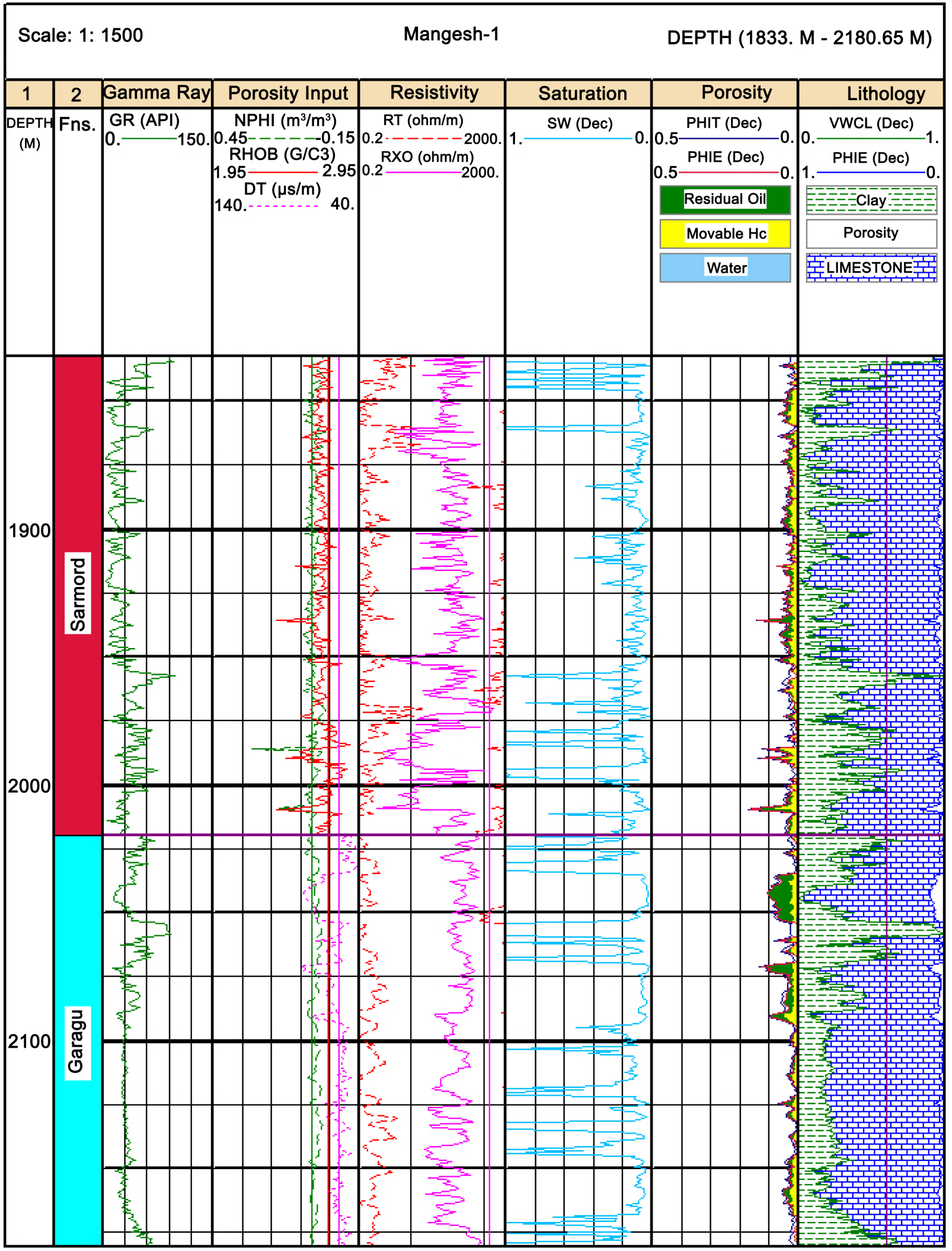

(b)

Figure 6. Computer Processed Interpretation (CPI) for the Sarmord and Garagu formations in Atrush-1 (a) and Mangesh-1; (b) Wells. 
In some points, the petrophysical characteristics of the Garagu and Sarmord formations in Mangesh-1 are slightly different from Atrush-1. The general values of porosity of the Sarmord and Garagu formations in Mangesh-1 Well are $0 \%-6 \%, 0 \%-5 \%(0.4 \%$ in average), respectively. These values are considered negligible to very poor porosity ratios.

Hydrocarbon movability is very useful to define the ability of hydrocarbon movement, recognizing the type of movable hydrocarbon, consequently the well productivity [25], and the trapped hydrocarbons in parts of the pore volume are called the residual oil saturation [26]. As mentioned earlier, the porosity values of the flushed zone are greater than water saturation, which indicates that the formations have good movable hydrocarbon content, especially in Mangesh-1 Well. The Presence of residual oil in a zone is possibly due to the type of hydrocarbons or low permeability, in which a zone of heavy hydrocarbons and low permeability is expected to occupy the residual hydrocarbon. On the other hand, the presence of movable hydrocarbons could indicate a zone of connected pores or/with light hydrocarbon. The Sarmord Formation, in Atrush-1 Well, is characterized by the presence of residual oil with little movable hydrocarbon in the upper part of the formation, but the Garagu Formation has no trace of hydrocarbon except in the middle part of the formation, which shows good movable hydrocarbon. From a total thickness of 180 meters, only 120 meters is considered as net pay zone from the Sarmord Formation, and the Garagu Formation has 60 meters net pay zone out of a total thickness of 182 meters. On the other hand, some movable oil with no to very little residual hydrocarbon has been noticed within Sarmord and Garagu formations in Mangesh-1. In Mangesh-1, out of a total 187 meters, there are only 3 meters net pay zone for the Sarmord Formation, and the Garagu Formation has a 5meters net pay zone from 160 meters thick. Based on these results, the Sarmord and Garagu formations from Atrush-1 have more chance than Mangesh-1 to be considered as a reservoir. This difference in porosity values, regardless of unroofing, is possibly due to the high amount of overburden at Mangesh-1 compared to the Atrush-1 wells.

\section{Conclusions}

In this study, petrophysical analysis was carried out to estimate the reservoir characteristics of the Sarmord and Garagu formations in Atrush-1 Well from Atrush Block and Mangesh-1 Well from the Sarsang Block. According to the analyzed results, in Atrush-1 Well, the Sarmord Formation has poor to fair porosity values in its lower part, while good porosity was recorded in its upper part. Regarding the Garagu Formation, a good porosity ratio was documented in its lower part and poor values from its upper part. Furthermore, the Sarmord Formation is characterized by residual oil with little movable hydrocarbon in the upper part; on the contrary, the Garagu Formation shows no signs of hydrocarbon as expected in its middle part, since it shows good movable hydrocarbon. Both Sarmord and Garagu formations in Mangesh-1 Well display low porosities, 
which are regarded as negligible to very poor porosity quality. In addition, insufficient movable oil with inadequate residual hydrocarbon has been noticed within Sarmord and Garagu formations in Mangesh-1 Well.

\section{Acknowledgements}

The authors would like to thank the staff of the Ministry of Natural Resource of Kurdistan Region-Iraq, particularly.

Mr. Muhammad Ameen Atrushi, for providing most of the data and information related to this work. Appreciation is extended to the HKN and TAQA oil companies for providing well data.

\section{Conflicts of Interest}

The authors declare no conflicts of interest regarding the publication of this paper.

\section{References}

[1] Asquith, G., Krygowski, D., Henderson, S. and Hurley, N. (2004) Basic Well Log Analysis. 2nd Edition, American Association of Petroleum Geologists, Tulsa, 244 p. https://doi.org/10.1306/Mth16823

[2] HKN Company (2013) Internal Report, the Final Well Report of Mangesh-1 Well. Unpublished Report.

[3] Shamaran Company (2012) Internal Report, the Final Well Report of Atrush-1 Well. Unpublished Report.

[4] Mamaseni, W.J., Naqshabandi, S.F. and Al-Jaboury, F.K. (2018) Petrophysical Properties of the Early Cretaceous Formations in the Shaikhan Oilfield/Northern Iraq. Earth Sciences Research Journal, 22, 45-52. https://doi.org/10.15446/esrj.v22n1.66088

[5] Edilbi, A.N.F., Mohammed, K.F., Sadeq, Z.H., Aldalawy, A.A., Zebari, B.G., Pirouei, M., Suramairy, R. and Ali, J.A. (2019) Source Rock Potential and Reservoir Characterization of the Lower Cretaceous Sarmord Formation in selected sections in Kurdistan Region-Iraq. Arabian Journal of Geosciences, 12, Article No. 647. https://doi.org/10.1007/s12517-019-4765-6

[6] Fouad, S.A.F. (2015) Tectonic Map of Iraq, Scale 1: 1000,000. 3rd Edition, 2012. Iraqi Bulletin of Geology and Mining, 11, 1-7.

[7] Stevanovic, Z., Markovic, M., Lawa, F.A., Ali, S.S., Karim, K.H., Omer, A., Hassan, I.O., Surdashy, A.M., Sherwani, G.H. and Aqrawi, A.M. (2004) Lithostratigraphic Map of Northern Iraq, Scale 1:50,000. Geological Survey of Iraq.

[8] Jassim, S.Z. and Buday, T. (2006) Late Tithonian-Early Turonian Megasequence AP8. In: Jassim, S.Z. and Goff, J.C., Eds., Geology of Iraq, Dolin, Brno, Prague and Moravian Museum, 450.

[9] Bellen, R.C., Dunnington, H.V., Wetzel, R. and Morton, D. (1959) Lexique Stratigraphique International. Asie, Iraq. Vol. 3C, 10a, Iraq, Paris, 333 p.

[10] Buday, T. (1980) The Regional Geology of Iraq. Vol. 1, Stratigraphy and Paleogeography. Dar Al-Kutub Pub, University of Mosul, Iraq, 445 p.

[11] Aqrawi, A.A.M., Goff, J.G., Horbury, A.D. and Sadooni, F.N. (2010) The Petroleum Geology of Iraq: Beaconsfield. Scientific Press Ltd., United Kingdom, 424 p. 
[12] Balaky, S.M., Abdula, R.A., Edres, M. and Perot, E.M. (2016) Facies Analysis and Depositional Environment of Garagu Formation (Valanginian-Hauterivian) in Gara Mountain, Gali Garagu, Sarsang District, Iraqi Kurdistan Region. Journal of Zankoy Sulaimani, Special Issue, GeoKurdistan II, 51-68. https://doi.org/10.17656/jzs.10471

[13] Mackertich, D. and Samarrai, A. (2013) The History of Hydrocarbon Exploration in Iraqi Kurdistan: 1901 to 2012. Geol-Soc-Zagros-Conference-Presentation.

[14] Archie, G.E. (1942) The Electrical Resistivity Log as an Aid in Determining Some Reservoir Characteristics. Transaction of the AIME, 146, 54-62. https://doi.org/10.2118/942054-G

[15] Timur, A. (1968) An Investigation of Permeability, Porosity, and Residual Water Saturation Relationships for Sandstone Reservoirs. Society of Petrophysics and Well-Log Analysts. 9th Annual SPWLA Logging Symposium, New Orleans, 23-26 June 1968.

[16] Wyllie, M.R.J. (1963) The Fundamentals of Well Log Interpretation. Academic Press, New York, $238 \mathrm{p}$.

[17] Hughes, B. (1992) Advanced Wireline and MWD Procedure Manual. Baker Hughes INTEQ, Technical Publications Group, Huston, Texas, USA, 192 p. https://www.coursehero.com/file/43211036/Advanced-Wirleline-MWD-Procedures -Manual-80459-A-1992pdf/

[18] Nnaemeka, E. (2010) Petroleum Reservoir Engineering Practice: Porosity of Reservoir Rocks. Dokumen Pub., Germany, 816 p.

[19] Selley, R.C. and Sonnenberg, S.A. (2015) Elements of Petroleum Geology. 3rd Edition, Elsevier, Amsterdam, 507 p.

[20] Crain, E.R. (1986) The Log Analysis Handbook. Penn-Well Publishing Company, Tulsa, $700 \mathrm{p}$.

[21] Rider, M. (1986) The Geological Interpretation of Well Logs. Blackie, Glasgow, 151-165.

[22] Schon, J.H. (Ed.) (2015) Physical Properties of Rocks: Fundamentals and Principles of Petrophysics. Developments in Petroleum Science, Vol. 65, Elsevier, Amsterda.

[23] Levorsen, A.I. (1967) Geology of Petroleum. C.B.S Publishers and Distribution, Delhi, 77-137.

[24] Gluyas, J. and Swarbrick, R. (2004) Petroleum Geoscience. Blackwell Publishing, Hoboken, 359 p.

[25] Hamada, G. (2013) Identification of Hydrocarbon Movability and Type of Reservoir Fluids Using Resistivity Logs and Ratio of P-Wave Velocity/S-Wave Velocity (Vp/Vs). SPE Asia Pacific Oil \& Gas Conference and Exhibition, Jakarta, October 2013, 1-13.

[26] Schlumberger (1989) Log Interpretation Principles and Application. Schlumberger Educational Services, Houston, SMP-7017. 